\title{
REVISITA À DESCONSTRUÇÃO DO MODELO JURÍDICO INQUISITORIAL*
}

Salo de Carvalho**

RESUMO: A investigação versa sobre a fundação e declínio do sistema inquisitório confessional. Desenvolve, como hipóteses desconstrutivas do modelo repressivo medieval, a recepção do discurso médico pela jurisprudência penal e o impacto do racionalismo e do humanismo. Conclui, todavia, que em virtude de um giro nas premissas fundantes do discurso processual, o sistema inquisitório confessional foi substituído por um modelo laicizado de idêntica natureza autoritária, obstaculizando o desenvolvimento e consolidação do sistema acusatório.

“(...) todo ataque dirigido contra o obscurantismo é impressionante por aquilo que nos mascara, e a rejeição dos medievais para fora da modernidade (do ponto de vista do discurso sobre o Poder), continua sendo uma extraordinária trapaça. Leiam, então, Kafka: o glosador reaparece nele com todas as letras e vem ordenar a fuzilaria. Vamos parar de rir da Idade Média, de suas técnicas do obscurecimento, sempre eludidas, sempre presentes" (Pierre Legendre).

* As conclusões expressas no artigo são frutos da pesquisa intitulada "Mal-Estar na Cultura Punitiva", realizada junto ao Mestrado em Ciências Criminais da PUC/RS (instituição financiadora).

** Advogado. Mestre (UFSC) e Doutor (UFPR) em Direito. Professor do Mestrado em Ciências Criminais da PUCRS.

\section{INTRODUÇÃO I: O MOTIVO DA REVISITA}

A versão original do texto $D a$ Desconstrução do Modelo Jurídico Inquisitorial foi redigida em 1994, como paper final da disciplina História das Instituições Jurídicas, ministrada pelo prof. Antônio Carlos Wolkmer, no mestrado em Ciências Jurídicas da Universidade Federal de Santa Catarina (UFSC).

Após sua entrega, o prof. Wolkmer realizou convite para publicar o trabalho, em forma de artigo, na primeira edição da coletânea Fundamentos de História do Direito (BH: Del Rey, 1996).

No ano de 1996, ostentava o título de Mestre e a qualidade de professor de Direito 
Penal em renomada Universidade gaúcha. Como o livro organizado pelo prof. Wolkmer estava no mercado com ótima aceitação, indicando a possibilidade de segunda edição, resolvi retomar a temática.

Naqueles dias que sucederam a defesa da dissertação, a notícia da segunda edição do livro e a vontade de atualizar (em realidade ampliar) o texto, obtive a notícia de que Jacinto Coutinho ministraria um módulo na Especialização em Direitos Humanos, na Faculdade na qual lecionava. Contatei a coordenadora do curso, profa. Sandra Vial, que imediatamente acenou a possibilidade de assistir as aulas. Tema: Sistemas Processuais Penais e Direitos Humanos.

Jacinto Coutinho iniciou sua exposição trabalhando a teoria dos sistemas processuais em Roma, de como ocorrera a incorporação do modelo acusatório grego pela República romana e de que forma, na transmutação ao Império, gradativamente a estrutura foi tomando contornos inquisitórios. No segundo momento, passou a operar no interior do sistema acusatório dos iudicium Dei, sem deixar de explicar, desde a filosofia, a economia e a psicanálise, o processo de ruptura do Medievo com o mundo Antigo. Finalmente, com Cordero, revelou a necessidade do burguês século XII cambiar o sistema, visto a intolerância com máquinas judiciárias tão rudimentares ( $v . g$. os procedimentos ordálios como o iudicium ferri candentis). Fundada a base histórica, após quatro horas de exposição, o professor afirmou estar pronto para tratar do sistema inquisitório.

Concílio de Verona (1184) e a coalisão do Papa Lúcio III e Frederico Barbaroxa; Bula Vergentis in Senium (1199) de Inocêncio III; Concílio de Latrão (1215); Editos de
Frederico II contra os cátaros (1231); criação da ordem dos Dominicanos por Gregório IX; Bula Ad Extirpanda de Inocêncio IV - "as estruturas emergem lentamente: no princípio são os delegados do Papa que inquirem; depois entram em cena os dominicanos; primeira aparição em Firenze, 20 de junho de 1227; quando Inocêncio IV emite a bula 'Ad extirpanda', 25 de maio de 1252, o aparato assume figuras definitivas". ${ }^{1}$ Desta forma, concluiu Jacinto Coutinho, a estrutura inquisitorial origina-se "no seio da Igreja Católica, como uma resposta defensiva contra o desenvolvimento daquilo que se convencionou chamar de 'doutrinas heréticas'. Trata-se, sem dúvida, do maior engenho jurídico que o mundo conheceu, e conhece". 2

Durante a aula, o professor, que havia lido meu artigo, publicamente criticou os equívocos que incorri no ensaio, gerando em mim e em alguns colegas, notadamente a amiga Maura Basso, desconforto. Pontuou a ausência de autores importantes para tratar o tema (Cordero, fundamentalmente) e a perspectiva errônea quanto à Ordonnance Criminelle de Luís XIV (1670), vigente no ancien régime, que, contrariamente do que eu afirmava, não teria determinado o declínio do sistema, mas sim a laicização do inquisitorialismo e a instrumentalização de uma forma de processo inquisitório com a presença de partes. Por outro lado, foi incisivo ao identificar o falseamento realizado por Napoleão ao instituir o "processo misto",

\footnotetext{
${ }^{1}$ CORDERO, Guida alla Procedura Penale. p. 46.

${ }^{2}$ COUTINHO, O Papel do Novo Juiz no Processo
} Penal. p. 36. 
com o intuito de preservar a essência inquisitiva, na edição do Code d'Instruction Criminelle (1808) - ilusão preservada ainda hoje por aqueles que advogam a existência de teoria geral do processo, sistema misto, verdade real, poderes instrutórios de 'juízes imparciais', reformas parciais entre outras fantasias.

O efeito da crítica não poderia ser outro: resolvi convencê-lo a me aceitar como orientando no Doutorado em Direito na Universidade Federal do Paraná (UFPR). Na redação da tese, publicada pela editora Lumen Juris sob o título "Pena e Garantias", dediquei os dois primeiros capítulos à configuração do sistema garantista (SG) de direito (processual) penal e sua antípoda, o sistema inquisitorial (SI).

Hoje, passados 10 anos do texto original, resolvi alterar seu conteúdo. O motivo da demora não sei explicar. Refugiar-me no "tempo" talvez fosse uma boa escapatória. Mas uma pista talvez possa servir como justificativa: após estes anos de vida acadêmica aprendi que ocultar os erros e esconder a falta (de conhecimento) revela postura arrogante que não condiz com o papel do professor-investigador.

Neste cenário, peço a paciência do leitor para propor algumas alterações.

A revisita, em realidade, procura corrigir alguns rumos equivocados, sem a pretensão (narcísica) de completar lacunas ou sanar contradições, visto que intermináveis. Imaginei apenas acrescentar pequenos, mas, creio, substanciais recortes, desde uma nova roupagem. Desta forma, procurei deixar o caminho menos tortuoso ao leitor, emprestando, nas pegadas de Cordero e
Jacinto Coutinho, um olhar crítico e não pasteurizado sobre tão fascinante tema.

A abordagem do Medievo e do sistema inquisitório no artigo, porém, segue o recorte original, qual seja, um olhar historiográfico, com algumas nuances jurídico-políticas, centrado sobretudo nas oscilações discursivas ocorridas na França.

A dedicatória, pois, não poderia ser outra senão para Antônio Carlos Wolkmer e Jacinto Coutinho, meus estimados mestres, com os quais sigo aprendendo diuturnamente.

\section{INTRODUÇÃO II: (RE)DEFINIÇÃO DA TEMÁTICA}

O rompimento com a tradição inquisitorial de suplícios e expiações, experiência que identifica o processo (de cognição e de execução) penal do Medievo, marca a vitória da 'racionalidade' e do 'humanismo' advogados pelos filósofos das luzes.

Sob o signo da intolerância e mascarada pela sacralização, a fase inquisitorial que se inicia com os Concílios de Verona (1184) e Latrão (1215) e que ganha subsistência com as Bulas Papais de Gregório IX (1232) e Inocêncio IV (1252), somente receberá incisiva crítica e reconhecida deslegitimação ao final do século XVII e início do século XVIII, quando a casta intelectual teórica e prática estrutura uma abordagem desqualificadora do aparato gótico. No entanto, embora as práticas inquisitoriais sejam formalmente erradicadas no século XIX, quando os Tribunais do Santo Ofício são definitivamente abolidos em Portugal (1821) e Espanha (1834), sua matriz material e ideológica predominará na legislação laica, orientando a tessitura dos sistemas penais da modernidade. 
Se a normatização dos sistemas inquisitórios ocorre com a edição das Bulas Papais, sobretudo a Bula Ad Extirpanda (1252), dois manuais proporcionarão sua praticidade: "Directorium Inquisitorum" (1376) e “Malleus Maleficarum” (1489). As duas principais obras de orientação das Inquisições (romano-germânica e espanhola) fornecerão as chaves de leitura que instrumentalizarão procedimentos baseados em denúncias anônimas e vagas, em estruturas probatórias centradas na confissão e na busca da "verdade material", bem como na prisão processual como regra - "um suspeito podia ser preso a qualquer momento, sem saber o que se queria dele. Nunca ficava conhecendo o nome de quem o acusou, nem lhe era comunicado o motivo da prisão, nem o lugar em que havia cometido o crime de que era acusado, nem com quem havia pecado". 3

Nítido que, para além do jurídico, inúmeras leituras são possíveis deste rico período histórico. Sua fecundidade, advinda da riqueza do tema, propicia análises a partir de diversos campos do saber, do viés psicanalítico pelo estudo do sadismo e da repressão do corpo, fundamentalmente o feminino, ${ }^{4}$ às essencialmente sociológicas e

\footnotetext{
${ }^{3}$ NOVINSKY, A Inquisição. p. 58-59.
}

4 Pierre Legendre questiona a atribuição antifeminina do sistema punitivo inquisitorial, entendendo ser uma fácil simplificação do problema. Ensina que "(...) a clivagem resultante do conjunto do dispositivo aprontado pelo Direito canônico não tem verdadeiramente nada a ver com alguma idéia de antifeminismo; o ignaro distinto hoje diz de bom grado: os medievais teriam montado com todas as peças a cena de um Direito masculino, fabricado pelos homens para o trote sexual e político das mulheres. Na realidade, as coisas não passam historiográficas como a da perseguição dos judeus, cristãos novos e de um sem número de culturas opositoras à tradição. $\mathrm{O}$ presente trabalho, todavia, propõe verificar as técnicas do procedimento inquisitorial e os seus discursos (des)legitimadores, sobretudo aqueles que geraram a revolução jurisprudencial no trabalho da magistratura francesa no século XVII.

No entanto, o estudo prescinde abordagem mais ampla, qual seja, análise do processo de secularização/secularismo das ciências e da repulsa destas às atitudes autoritárias da Igreja. Tal leitura realizar-se-á a partir de Dussel.

\section{O APARELHO INQUISITORIAL}

"Há uma coisa apenas que excita os animais mais do que o prazer: é a dor. Sob tortura tu vives como sob o efeito de ervas que produzem alucinações. Tudo o que ouviste contar, tudo o que leste, volta à tua mente como se fosses transportado, não ao céu mas ao inferno. Sob tortura dizes não apenas o que quer o inquisidor, mas também aquilo que imaginas que possa lhe dar prazer, porque se estabelece uma relação (esta sim, realmente diabólica) entre tu e ele... Eu sei estas coisas, Ubertino, eu também fiz parte daquele grupo de homens que acreditam poder produzir a verdade com oferro incandescente" (Umberto Eco).

segundo esse simplismo". Assim, sustenta que a escolástica não separa os machos das fêmeas, “(...) não designa a verdade da cultura segundo este recorte; ela indica duas zonas, dois espaços do refúgio diferentemente sagrados, mas no interior dos quais se acham igualmente repartidos homens $e$ mulheres, e que, desse ponto de vista, negam realmente os dois sexos; descobre-se aí o enunciado, segundo os termos Sic e Non (famoso título abelardiano), Sim e Não, o único conflito, o qual é tratado por analogia e por referências às garantias que lhes dá a teologia" (LEGENDRE, O Amor do Censor: ensaio sobre a ordem dogmática. p. 118). 
O aparelho inquisitorial, anteriormente testado no período da Roma Imperial, ressurge nas práticas judiciárias medievais quando da necessidade de ampliação da malha repressiva. A partir da necessidade de controlar conjuntamente criminalidade comum e heresia (crime de consciência), o mecanismo permite a ampliação do rol de culpáveis, englobando em suas tipificações qualquer oposição ao "saber oficial". Estabelece-se, pois, estrutura maximizada e onipresente de poder que não admite a existência da alteridade, sendo qualquer manifestação identitária diversa da tolerada pelo clero adjetivada como (delito de) heresia.

$\mathrm{O}$ historiador Brian Levack enumera quatro circunstâncias que propiciaram a modificação no sistema (processual) punitivo, deflagrando a onda penalógica conhecida como "caça às bruxas". Segundo o autor, o primeiro fato que instiga a mudança nas regras processuais é a superação do procedimento acusatório (iudicium Dei), predominante na Europa continental até o século XIII. Com a "redescoberta" do Direito Romano, sobretudo com a revitalização do “Corpus Iuris Civilis” no século XII pela Universidade de Bolonha e a posterior inserção das glosas, ${ }^{5}$ o clero instiga a

5 Sustenta Legendre que a glosa inserida no emaranhado disperso de escritos antigos integra o Corpus Iuris, criando as chaves de interpretação e vivificando o texto - “(...) uma massa amorfa, previamente constituída, de obras antigas, inumeráveis e isoladas uma das outras, formando um texto morto, que pedem para a vida do sistema as operações do compilador que recorta e aproxima seus fragmentos. Sobre esta base toma a consistência um corpus iuris, um corpo do Direito ao qual vem se enxertar a glosa, e que reconhece nos seus limites $e$ seus desvios uma dialética aperfeiçoada" (LEGENDRE, O Amor..., p. 73) formalização e a mudança nos procedimentos - "a Igreja se aproveita do texto do corpus iuris civilis para escorar sua própria organização e desenvolver mecanicamente sua teocracia radical". ${ }^{6}$ Lembra Cordero que "o saber técnico imposto pelas fontes romanas exige novas máquinas instrutórias; se alguém deve ou não ser punido é assunto cientificamente regulável; em primeiro lugar, devem ser reexaminados os fatos, com métodos adequados à cultura dominante; depois conhecedores do Corpus Iuris ou dos cânones dirão quanto vale in iure o acontecido. Os antigos rituais não distinguiam as duas questões, facti e iuris".?

Dentre as principais vantagens do novo método, pode-se destacar (a) o caráter público das denúncias, não mais restritas à vítima ou aos seus familiares, aliada (b) ao sigilo da identidade do delator; (c) a inexistência de separação entre as figuras de acusador e julgador, sendo lícito a este realizar a imputação, produzir a prova e julgar o acusado; (d) o sistema tarifado de provas e sua graduação na escala da culpabilidade, recebendo a confissão o máximo valor (regina probatio), ${ }^{8}$ e (e) a autorização irrestrita da tortura como mecanismo idôneo para obtenção de confissões.

${ }^{6}$ LEGENDRE, $O$ Amor..., p. 91.

${ }^{7}$ CORDERO, Guida..., pp. 43-44.

8 “A confissão, contudo, está explicitamente relacionada pelos teólogos à doutrina das causas do Mal e dos meios para dela se desfazer, conjurar a potência sobre-humana de Satã, ou restituir ao Homem sua Salvação após a Queda" (LEGENDRE, O Amor..., p. 136). 
A importância da utilização da tortura para a conquista da "verdade real"9 foi tamanha que Levack aponta como a segunda circunstância determinante na alteração do sistema. Sustenta o autor que a tortura disseminou o modelo repressivo, aumentando gradativamente as possibilidades de condenação por heresia devido à facilidade na obtenção da prova suprema - "o Direito canônico não tendo determinado este ou aquele suplício em particular, os juízes podem se servir daqueles que eles acreditarão serem os mais apropriados para tirar do acusado a confissão do seu crime". ${ }^{10}$ Exemplo significativo da veemência no uso deste meio para obtenção da prova encontra-se na primeira edição da obra de Eymerich (1376): “É costume louvável torturar criminosos, mas reprovo esses juízes sanguinários que inventam tormentos de tal modo cruéis que os acusados morrem ou perdem alguns membros durante a tortura". ${ }^{11}$

Como terceiro fator da expansão dos instrumentos inquisitórios, Levack aponta a utilização do modelo judicial leigo para os crimes de natureza espiritual. Segundo o autor, "desde o começo da grande caça às bruxas os tribunais seculares dos estados

\footnotetext{
${ }^{9}$ Cordero, ao avaliar o impacto da tortura como meio judicial de prova, constata: "o instrumento inquisitório desenvolve um teorema óbvio: culpado ou não, o indiciado é detentor das verdades históricas; tenha cometido ou não o fato; nos dois casos, o acontecido constitui um dado indelével, com as respectivas memórias; se ele as deixasse transparecer, todas as questões seriam liquidadas com certeza; basta que o inquisidor entre na sua cabeça. Os juízos tornam-se psicoscopia” (CORDERO, Guida..., p. 48).

${ }^{10}$ LEGENDRE, O Amor..., p. 99.

${ }^{11}$ EYMERICH, Manual dos Inquisitores. p. 47.
}

europeus ocidentais também participaram da perseguição, quer cooperando com o trabalho dos tribunais eclesiásticos, quer processando bruxas por conta própria. À medida que a caça foi evoluindo, os tribunais seculares assumiram um papel ainda maior no processo, enquanto o dos tribunais [confessionais] declinou". ${ }^{12}$

Com a identificação formal entre as categorias delito e pecado, e com a recuperação do Direito Romano imperial, a nascente burocracia européia ocidental é ocupada na rede repressiva, sendo sua absorção corolário da natureza jurisdicional "mista" do crime de lesa-majestade divina. O próprio Malleus Maleficarum, no capítulo "Que trata das Medidas Judiciais no Tribunal Eclesiástico e no Civil a Serem Tomadas Contra Bruxas e Também Contra Todos os Hereges”, tópico terceiro, “De Como o Processo há de ser Concluído como Pronunciamento de uma Sentença Definitiva e Justa”, define: "[a feitiçaria] (...) não há de ser confundida com outras heresias simples, já que é notório não se tratar de crime puro e simples, mas de crime parcialmente eclesiástico e parcialmente civil". ${ }^{13}$ Assim, lembra João Bernardino Gonzaga que "passaram a coexistir três jurisidições penais: a central, exercida pelos juízes do rei; a local, de cidades ou, conforme o país, de regiões mais ou menos extensas; a eclesiástica, restrita às questões que importavam à Igreja". ${ }^{14}$

\footnotetext{
12 LEVACK, A Caça às Bruxas. p. 80.

13 KRAMER \& SPRENGER, O Martelo das Feiticeiras. p. 444.
}

14 GONZAGA, A Inquisição em seu Mundo. p. 26. 
Em decorrência da pluralidade de jurisdições, devido à atuação conjunta entre Estado e Igreja na repressão penal, surgem conflitos de competência cuja resolução ocorre pela regra de prevenção. Lembra João Bernardino Gonzaga que o Tribunal ao qual primeiramente era apresentada a causa resguardava competência para processar e julgar, salvo nos casos em que existiam Cortes especializadas $-v \cdot g$. a proeminência de a Igreja julgar os tipos de heresia e a reserva do Estado na execução das penas.

Paralelo à mudança nos procedimentos, à utilização da tortura e à capacitação da burocracia secular para julgamento dos crimes de lesa-majestade divina, Levack apontará como quarta condição para o agigantamento do sistema inquisitorial a regionalização (interiorização) dos Tribunais. A distância dos centros urbanos, aliada à possibilidade de julgamento das heresias nos Tribunais locais, possibilitou avanço significativo do modelo de repressão inquisitório, sobretudo porque a superstição, a intolerância e o medo contagiavam aldeias sem qualquer tipo de perspectiva senão a da crença. Universos de angústia encontravam na eliminação do "mal" uma válvula de escape para suas mazelas.

Instituído burocraticamente o modelo repressivo, o sistema processual inquisitório caracterizar-se-á pela exclusão do contraditório, ausência de ampla defesa e inviabilização da presunção de inocência. A insuficiência de provas e/ou sua dubiedade não geravam absolvição, mas, ao contrário, qualquer indício equivalia a uma semiprova, que comportava juízo de semiculpabilidade e uma semicondenação. ${ }^{15} \mathrm{Na}$ trilha do processualista italiano Franco Cordero, ${ }^{16}$ pode-se identificar o estilo inquisitorial a partir de duas constatações: ( $1^{\mathrm{a}}$ ) a sobrevalorização da imputação em relação à prova, configurando o primado das hipóteses sobre os fatos; e ( $\left.2^{\mathrm{a}}\right)$ a conversão do processo em psicoscopia, ao estabelecer rito fatigante e isento de forma.

O modelo estabelece, pois, no magistrado, quadros mentais paranóicos e tendências policialescas, visto que, ao invés de o juiz "se convencer através da prova carreada para os autos, inversamente, a prova servia para demonstrar o acerto da imputação formulada pelo juiz-inquisidor". ${ }^{17}$ Assim, o réu, longe de ser um sujeito (de direito) processual, é um mero objeto de investigação: o imputado detém com exclusividade a verdade histórica (material) - "o inquisidor investiga, procurando buscar signos do delito, e trabalha sobre os acusados, porque, culpados ou inocentes, sabem tudo o que se requer para decisões perfeitas; tudo se resume a fazê-los dizer". ${ }^{18} \mathrm{E}$ se é o único detentor de uma 'verdade' não mais passível de experimentação empírica, ou ainda de uma verdade unicamente sua, necessária sua exposição sem reservas - "o estilo inquisitório multiplica os fluxos verbais: é preciso que o imputado fale; o processo se transforma em

15 Quanto ao regime probatório da Inquisição e a formulação de juízos de semiculpabilidade pelos indícios, verificar FOUCAULT. Vigiar e Punir. pp. 11-61.

\footnotetext{
${ }^{16}$ CORDERO, Guida... p. 51.

17 JARDIM, Ação Penal Pública. p. 24.

${ }^{18}$ CORDERO, Procedura Penale. p. 580.
} 
sonda psíquica. O inquisidor trabalha livremente, indiferente aos limites legais, mas recolhe toda sílaba: a obsessão microanalítica desenvolve um formalismo gráfico; nenhum fato é realmente um fato enquanto não figure no papel". ${ }^{19}$

\section{SECULARIZAÇÃO E SECULARISMO}

O termo secularização é utilizado para definir o processo de ruptura da cultura eclesiástica com as doutrinas filosóficas e as instituições jurídico-políticas, que ocorreu gradualmente a partir do século $\mathrm{XV}$, objetivando expurgar da esfera civil o domínio da religião, sobretudo da Igreja Católica. Lembra Baubérot, ser “(...) possível afirmar que, até 1789, a Igreja Católica proporcionou, na França, os principais fundamentos da Cultura moral comum. Ela definia, no essencial, o que parecia 'bem' ou 'mal'. A ordem 'temporal' produzia principalmente relações de força - aspecto muito importante na matéria, enquanto a ordem espiritual produzia a cultura religiosa e moral. Sua aliança - e às vezes seu conflito - estabeleceu os limites da história da França". ${ }^{20}$

Dussel, em apêndice ao segundo tomo da obra "Caminhos de Libertação LatinoAmericana" denominado "Da Secularização ao Secularismo da Ciência Européia, desde o Renascimento até o Iluminismo", delimita a gênese do processo de secularização da(s) ciência(s), no ano de 1440, com a obra

\footnotetext{
${ }^{19}$ CORDERO, Procedura... p. 329.

${ }^{20}$ BAUBÉROT, Laicidade. p. 17.
}

“De Docta Ignorantia” de Nicolau de Cusa. A inspiração secularizadora ganharia relevo em 1781 com "Crítica da Razão Pura”, de Kant, atingindo o apogeu com as publicações de Feuerbach (1841) e Nietzsche (1883) "A Essência do cristianismo" e "Assim falou Zaratustra", respectivamente.

$\mathrm{O}$ avanço das ciências causou profundo abalo no saber confessional. Quando Copérnico (1473-1543) destrona a Terra e afirma a impossibilidade de o Universo ter um centro, coloca em dúvida a estrutura do pensamento Ocidental desenvolvida durante séculos. Não por outro motivo Freud identificará na doutrina de Copérnico a primeira ferida narcísica da cultura ocidental, visto o rompimento com símbolos "etern(izad)os" e suas formas de interpretação. ${ }^{21}$ As conseqüências da exposição desta ferida são visualizadas perfeitamente no julgamento de Giordano Bruno, principal seguidor de Copérnico, queimado vivo em Roma (1600) após ser condenado pela Inquisição.

Não bastasse o descentramento no plano teorético, Colombo comprova a teoria da esfericidade e a Terra passa a ser encarada como um astro qualquer. Mais, o

${ }^{21}$ Freud, em um ensaio publicado em 1917 na Hungria, enunciou as graves ofensas que a investigação científica produzira no narcisismo geral (amor próprio da Humanidade). Primeiramente o homem, seguindo suas impressões sensoriais, acreditava que a Terra, sua sede, se encontrava em repouso no centro do Universo, e o Sol, a Lua e os planetas giravam ao seu redor - "la situación central de la Tierra le era garantia de su función predominante en el Universo, y le parecia muy de acuerdo con su tendência a sentirse dueño y señor del Mundo." Com os trabalhos de Copérnico ocorre 
'achamento' 22 revela a existência de um mundo totalmente outro, inocente em relação às instituições e aos dogmas cristãos. O Novo Mundo inspira Etienne de la Boétie a negar a sujeição do homem no Discurso da Servidão Voluntária ou O Contra Um (1577), e dá os instrumentos para Hobbes - Tratado sobre o Cidadão (1642) e Leviatã (1651) -, Locke - Segundo Tratado sobre o Governo (1690) - e Rousseau - Discurso sobre a Origem e o Fundamento da Desigualdade entre os Homens (1755) e Do Contrato

a destruição desta 'ilusão narcisista', e o “amor proprio humano sufrió su primera ofensa: la ofensa cosmológica" (FREUD. Una dificultad del Psicoanalisis. p. 2.434).

Ao longo da evolução cultural, o homem autointitulou-se soberano de todos os seres que habitavam a Terra, negou-lhes razão e atribuiu-se uma alma imortal e uma origem divina que lhe permitiu romper os laços com a animalidade. No entanto, as investigações de Darwin puseram fim à 'exaltação do homem': "el hombre no es nada distinto del animal ni algo mejor que él; procede de la escala zoológica y está proximamente emparentado a unas espécies, y más lejanamente, a otras. Sus adquisiciones posteriores no han logrado borrar los testimónios de su equiparación, dados tanto en su constitución física como en sus disposiciones anímicas. Esta es la segunda ofensa - la ofensa biológica - inferida al narcisismo humano" (FREUD. Una dificultad... p. 2.434).

A última ferida narcísica, e, segundo Freud, a mais sensível, seria a de natureza psicológica. Com a noção de inconsciente, o reduto da superioridade humana, a consciência, é destronado. A consciência deixa de ser soberana na estrutura psíquica do indivíduo e o eu, no funcionamento psíquico, é alijado da autonomia. Desta maneira, este 'descentramento do sujeito' implicaria pelo menos três descentramentos: "o descentramento da consciência para o inconsciente; o descentramento do eu para o outro; e o descentramento da consciência, do eu e do inconsciente para as pulsões" (FREUD. Una dificultad... p. 2.434).

22 O termo é utilizado por BORNHEIM. A Descoberta do Homem e do Mundo. p. 18.
Social: ou princípios do Direito Político (1757) - visualizarem a plenitude da igualdade e da liberdade no estado originário (de natureza).

Com a crise instaurada no seio da tradição, pois durante muitos séculos a Igreja monopolizara a produção científica e agora, para manter seus dogmas, necessita negar seus frutos, ${ }^{23}$ demonstra Dussel que ao pesquisador restavam duas soluções: o secularismo, opção que estabelecia a negação da teologia em prol da ciência; ou o concordismo, alternativa que impunha a busca incessante de adequação, muitas vezes forçada, das descobertas à cristandade. ${ }^{24}$

23 "Com efeito, a Igreja encontrava-se numa situação difícil. Por um lado promovia todo um movimento científico a partir da própria Roma. Mas, por outro lado, não se aceitavam os frutos de suas pesquisas. Em que consistia esta aparente contradição? Trata-se de uma ambígua confusão entre as estruturas transculturais da fé e as estruturas de uma dada cultura:a latino-mediterrânica, da cristandade medieval. A cristandade, seja bizantina ou latina, surgiu no século IV, a partir do triunfo de Constantino. A cristandade aceitou de fato muitas das estruturas que tinham resistido à crítica dos Padres da Igreja, inspiradas na Bíblia e na tradição. Mas não se tinham percebido de que estas estruturas, mesmo as da Bíblia, constituíam todo um condicionamento cultural necessário, mas não o único possível: juntamente com a língua aceitaram-se hipóteses astronômicas, etnológicas, físicas, geográficas, medicinais, históricas, psicológicas, políticas. Essas estruturas, difíceis de detectar, constituíram o a priori cultural, o óbvio da cristandade" (DUSSEL. Da Secularização ao Secularismo da Ciência Européia, desde o Renascimento até o Iluminismo. p. 212/11).

24 “(...) os homens de ciência, que na sua origem foram quase que exclusivamente homens da Igreja, sacerdotes, viram-se obrigados a cometer um dos erros inevitáveis: ou cair no concordismo (isto é, forçar a Bíblia ou a tradição para fazê-las 'concordar' com as suas conclusões científicas), ou desviar-se claramente da secularização para o secularismo, opondo-se à Igreja ou pelo menos a muitos dos seus teólogos" (DUSSEL. Da Secularização... p. 213). 
A hipótese de negação absoluta da teologia estabelecia a noção de um mundo essencialmente profano, dessacralizado. A oposição radical do secularismo - falsa alternativa, segundo Dussel - determinava uma laicização alheia do divino e em oposição frontal aos dogmas da Igreja, voltada ao enaltecimento de uma idéia de ciência plenamente capaz de compreender a natureza. Em decorrência desta negativa aos dogmas de fé, os adeptos do secularismo passariam, inevitavelmente, a ser encarados como heréticos, pois, em realidade, apresentar-se-iam como "opositores de consciência". Não menos ingênua, aponta o filósofo, a perspectiva do concordismo, caminho encontrado por inúmeros cientistas. Entendido como alternativa única ao cientista, o secularismo passa da fase panteísta (o mundo é visto como uma emanação do divino), para o período deísta (admite a existência de Deus mas nega a Revelação e a Providência) para, finalmente, quedar-se no ateísmo, negando a personalidade de Deus ou afirmando-o como valor e/ou como um não-ser. ${ }^{25}$

No entanto, importante perceber que a antinomia (necessária) estabelecida entre ciência e religião é equivocada, tendo gerado, como salienta Dussel, drásticos efeitos, sobretudo por se entender a ciência como destituída de fé, herética ou errada. ${ }^{26}$

25 Neste sentido, conferir DUSSEL. $D a$ Secularização... pp. 216-218.

26 “....) a ciência moderna vinha a substituir muitas expressões nítidas (tais como a centralidade ou imobilidade da terra, as cronologias hebraicas ou romanas etc.). $O$ repúdio às grandes intuições de um Galileu em astronomia; de um Simon em filologia; de um De Clave, Bitaud e Villon em geografia

\section{O DECLÍNIO DO SISTEMA INQUISITÓRIO CONFESSIONAL}

"(...) ao passo que as neuroses de nossos poucos psicológicos dias de hoje assumem um aspecto hipocondríaco e aparecem disfarçadas como enfermidades orgânicas, as neuroses daqueles antigos tempos surgem em trajes demoníacos (...). Aos nossos olhos, os demônios são desejos maus e repreensíveis, derivados de impulsos instintuais que foram repudiados e reprimidos. Nós simplesmente eliminamos a projeção dessas entidades mentais para o mundo externo, projeção esta que a Idade Média fazia" (Sigmund Freud).

Embora as "ciências" tenham antecipado o questionamento da legitimidade dos princípios de fé, juridicamente só a partir do século XVII inicia-se o processo de

(condenados pela Sourbonne); da química, que desde Paracelso (1493-1561) sempre foi suspeita, porque era confundida com a alquimia e a magia; de Priestley (1733-1804), perseguido pelos anglicanos; dos primeiros médicos (pelas dificuldades na dissecação ou pela proibição da inoculação das vacinas no caso Boyer, condenado pela Sourbonne) e de tantos e tantos outros, esse repúdio transformou a saudável secularização num secularismo anticristão. Pelo menos, foi uma de suas causas e certamente não foi a menor. A cristandade foi protegida por algum tempo graças aos esforços de muitos cristãos, entre eles Bossuet, mas com isso alargaram ainda mais as portas da incredulidade, indiferença e secularismo europeu do século XVIII. Montesquieu (1689-1755), Voltaire (1694-1778), Rousseau (1712-1778) e a revolução francesa poderiam ter sido um movimento positivo e não um secularismo anticatólico. A Igreja não recebeu a ciência como sua filha, mas com receios e contra a sua vontade. A falsa antinomia ciência-cristandade impossibilitou a maturação. De qualquer modo, só aqueles que descobriram a transcendência supracultural da fé na própria queda do 'antigo esquema' compreenderam desapaixonadamente a positividade da secularização" (DUSSEL. Da Secularização... p. 225/26). 
desconstrução das verdades reveladas pelo clero. Com a recepção do discurso médico no que tange à negativa da causalidade demoníaca de inúmeras enfermidades, o saber jurídico passará a desconfiar da generalização das imputações do crime de heresia, impulsionando um movimento de ruptura com o sistema penal medieval.

Em toda Europa continental, mas sobretudo na França, a crítica (jurisprudencial) à assimilação de inúmeras "doenças” como “delito" passa, necessariamente, pela revisão das definições constantes no Malleus Maleficarum, "verdadeira codificação de demologia" 27 segundo Legendre. O manual punitivo redigido pelos dominicanos Kramer e Sprenger, publicado em 1484, quando de sua instauração pela Bula Papal de Inocêncio VIII, após ser aprovado pelos eruditos da Universidade de Teologia de Colônia, instrumentalizou o primeiro modelo integrado de repressão na história do Ocidente, a partir da conexão de categorias criminológicas, criminalísticas, penais e processuais penais. ${ }^{28}$

Lecionam Zaffaroni, Batista, Slokar e Alagia que, de maneira sistemática e com alto nível de racionalização teórica, o Malleus Maleficarum recolheu a experiência punitiva

\footnotetext{
${ }^{27}$ LEGENDRE. O Amor... p. 138.
}

28 “O Malleus é a obra teórica fundacional do discurso legitimador do poder punitivo na etapa de sua consolidação definitiva, pois constitui o primeiro modelo integrado de criminologia e criminalística com direito penal e processual penal" (ZAFFARONI, BATISTA, SLOKAR e ALAGIA Direito Penal Brasileiro p. 511). dos séculos anteriores, fundando uma visão policial do saber da qual se nutrem constantes teorias de defesa social ilimitadas, inaugurando a era dos modelos penais totais. No âmbito criminológico, estabelece um discurso etiológico plurifatorial baseado na potencialização da gravidade do delito, na inferioridade dos delinqüentes (fundamentalmente da mulher e das minorias sexuais) e na predestinação ao crime. Em relação ao discurso penal, submete-o de forma extremada aos "modelos de autor", sendo o conjunto de signos que identificam o delito tão amplo que inexiste conduta da qual não se possa ser suspeito. Outrossim, inaugura a lógica do direito penal de periculosidade. Quanto ao processo, concentra os poderes de instrução na figura do juiz, não necessitando sequer acusador, apenas um tribunal de investigação. ${ }^{29}$

A máquina inquisitiva de repressão penal institucionalizada, ao sintonizar o conjunto dos diversos discursos penais (criminalístico, criminológico, penal e processual penal) e direcioná-los à punição do herege, estabelece regime deveras rigoroso de imposição gótica de sofrimento, que tende a se transmutar, na terminologia weberiana, em tipo ideal. Não é demasiado, pois, recordar as lições já apontadas de Jacinto Coutinho: "trata-se, sem dúvida, do maior engenho jurídico que o mundo conheceu, e conhece". ${ }^{30}$

${ }^{29}$ ZAFFARONI, BATISTA, SLOKAR e ALAGIA. Direito Penal... pp. 510-515.

${ }^{30}$ COUTINHO. O Papel... p. 36. 


\subsection{As dúvidas instigadas pelo discurso médico e sua recepção pela jurisprudência francesa}

Robert Mandrou, na obra Magistrados e Feiticeiras na França do Século XVII, afirma que as primeiras críticas públicas contra os excessos punitivos gerados pelo sistema inquisitorial delineado no Malleus Maleficarum foram apresentadas pelo Médico Wier, no livro De Praestigiis Daemonum et incantationibus et Veneficiis (1563). ${ }^{31}$ A obra do médico renano, seguidor de Cornelius Agrippa, não chega a negar a inexistência dos pactos demoníacos muito menos questiona a legitimidade dos Tribunais da Inquisição. Contudo, sua

31 Zaffaroni, Batista, Slokar e Alagia igualmente sugerem esta antecipação de Wier: "pode ser considerada decisiva a investigação de Christian Thomasius, quem desnudou publicamente a vacuidade pensante do Malleus em sua famosa tese defendida a 12 de novembro de 1701 e publicada, na tradução alemã de Johann Reichen, em Marburgo, em 1704, a partir da qual se inicia a decadência do pensamento defensor do delito de bruxaria; não obstante, Thomasius teve ilustres antecessores, entre os quais o mais profundo foi o jesuíta Friedrich von Spee von Lengenfeld (15911635), que antecipou seus argumentos e, inclusive, em certa medida, pode ser considerado o ascendente mais distante de Beccaria. Spee havia sido designado confessor das vítimas da Inquisição, mas sua obra não teve eco em sua época e ele deve ter sido obrigado a publicá-la anonimamente em 1631, bem como seu nome foi resgatado muito tempo depois, graças a Leibnitz. Parece que em seus argumentos, Spee seguiu a linha traçada por outro jesuíta, Paul Layman (1575-1635), em sua Teologia Moral. Costuma-se assinalar também que, em 1563, o Dr. Jophannes Wier (ou Weyer) (1516-1588), de Dusseldorf, publicou, na Basiléia, o primeiro livro contra o Malleus, que teve seis edições latinas durante a vida do autor" (ZAFFARONI, BATISTA, SLOKAR e ALAGIA. Direito Penal... p. 515/16). intensa prática da medicina entre os anos de 1550 e 1578 junto ao Duque Clèves Juliers possibilitou diagnosticar em vários pacientes doenças como "humor melancólico" e "velhice caduca", as quais estariam sendo confundidas com bruxaria. Desta forma, sua obra descreve casos e sugere práticas medicinais para o tratamento (não punitivo) e cura dos doentes, excluindo a intervenção de prima ratio dos Tribunais Inquisitoriais. ${ }^{32}$

A réplica é imediata e contundente. Jean Bodin, no livro intitulado Démonomanie des Sorciers, ridiculariza e desqualifica a experiência adquirida por Wier, advogando haver verdadeira "infecção satânica" na sociedade francesa, apelando veementemente aos magistrados das mais altas cortes para que fossem incansáveis na repressão aos crimes de feitiçaria. Lembra Mandrou que "nenhuma resposta foi tão vigorosa quando a de Jean Bodin, célebre sábio e erudito angevino, que escreveu para refutar esse 'pequenino médico' renano quinhentas páginas virulentas, freqüentemente sarcásticas, injuriosas às vezes, e de uma lógica imperturbável. A 'Démonomanie des Sorcies' foi escrita para denunciar o crime mais execrável que jamais existiu (...)". 33

Apesar da severa defesa da luta contra a heresia proferida por Bodin, pode-se dizer que, após as manifestações de Wier, aliadas aos significativos avanços das ciências médicas, inúmeros casos de "intervenções diabólicas" passam a ser diagnosticados como enfermidades naturais (simulações histéricas, melancolias, epilepsias entre outras).

${ }^{32}$ MANDROU. Magistrados e Feiticeiras na França do Século XVII. p. 106.

${ }^{33}$ MANDROU. Magistrados e Feiticeiras... p. 107. 
Mandrou narra episódio acontecido em 1589 que demonstra perfeitamente esta afirmação. Em decorrência de recursos contra condenação por feitiçaria, o Tribunal de Paris designa quatro médicos para que examinem onze condenados. Ao contrário do juízo condenatório de origem, "os quatro médicos não reconheceram senão pobres miseráveis 'depravados em sua imaginação' que nem mesmo apresentavam as 'marcas' de insensibilidade [prova do contato demoníaco] assinaladas pelos juízes de primeira instância, e concluem pela absolvição (com o que a corte concorda)". 34

No mesmo período, "o Parlamento [Tribunal] de Dijon pronunciou duas sentenças que vão contra os procedimentos habituais, não somente porque não entregam os condenados à fogueira, mas porque fazem intervir as autoridades religiosas que devem velar pela melhor educação cristã de suas ovelhas: os progressos da feitiçaria são atribuídos a uma falha dos curas, como se se tratasse de uma superstição pagã̄".35

Em 1624, após inúmeras decisões reformando sentenças condenatórias pelo delito de heresia, o Tribunal de Apelação de Paris institui recurso obrigatório, impedindo que os juízes locais decidam em última instância sobre os crimes de Lesa Majestade Divina - "todos os processos sobre os crimes de sortilégio cujas conclusões são sentenças que impliquem a tortura, a morte e todas as outras penas corporais, são levados a

\footnotetext{
${ }^{34}$ MANDROU. Magistrados e Feiticeiras... p. 132.

${ }^{35}$ MANDROU. Magistrados e Feiticeiras... p. 129.
}

ele [Tribunal], mesmo se os acusados não desejaram apresentar recurso, pretexto alegado usualmente pelos juízes ordinários para executar imediatamente a sua sentença". ${ }^{36} \mathrm{O}$ descumprimento da ordem do Tribunal passa a submeter juízes faltosos a sanções.

Todavia, é a partir de 1640 que a feitiçaria deixará de ser vinculada à idéia de delito, imperando "uma nova concepção de um crime que deixa de ser crime por não depender mais senão de uma medida terapêutica. (...) de fato, esses processos de grande repercussão provocaram a tomada de consciência decisiva, no mundo judiciário mais vivo, mais informado e também mais audacioso. É o prelúdio do refluxo". ${ }^{37}$

Os impulsos reformadores da concepção do "pacto demoníaco" e das feitiçarias, advindos da medicina e gradualmente incorporados na jurisprudência, instigam uma nova forma de gestão de problemas até então vistos exclusivamente sob o enfoque criminal. Em assim sendo, a partir do final do século XVI, torna-se comum os juízes dos Tribunais de Apelação aplicarem clemências

\footnotetext{
${ }^{36}$ MANDROU. Magistrados e Feiticeiras... p. 281. Em realidade, desde a Ordonnance Villers-Cotterêt, editada por Francisco I, em 1539, havia previsão dos recursos de ofício - artigo 163: "todas as sentenças e julgamentos pronunciados pelos juízes ordinários e implicando tortura, morte civil ou natural, mutilação, banimento ou galés devem competir imediatamente e sem mediação às cortes soberanas sem qualquer etapa intermediária e sem que os juizes subalternos possam apor-se a isso". No entanto, o descumprimento da norma pela magistratura local, sob a alegação da falta de interesse do condenado em recorrer, levou o Tribunal a impor o cumprimento da regra.

${ }^{37}$ MANDROU. Magistrados e Feiticeiras... p. 162.
} 
em face da não constatação dos pactos e dos atos de bruxaria, mormente o efeito do perdão vir seguido de internações compulsórias nos "hospitais para loucos".

Como visualiza Dussel, a ciência moderna punha em questão certos princípios considerados de fé, como, entre outros, “(...) a aceitação da causalidade demoníaca das enfermidades. (...) As grandes descobertas [científicas do Renascimento e do Iluminismo] punham por terra estruturas inconsistentes de um antigo esquema". ${ }^{38}$

Não é escopo do trabalho analisar se estas decisões que remetiam os "doentes da alma" aos sanatórios instituem ou não uma nova economia de poder e um novo e sofisticado aparelho de estigmatização e controle social. ${ }^{39} \mathrm{O}$ que cabe afirmar é que, no campo do jurídico, a jurisprudência, a partir da recepção de um discurso externo, rompe com a univocidade dos julgamentos, sendo tal processo fundamental para a cisão da antiga concepção de crime-pecado, proporcionando efetivo avanço no que se refere à busca da laicização do direito e do processo penal.

\subsection{Os impulsos legislativos subseqüentes}

O historiador Brian Levack considera três as causas fundamentais para o declínio das condenações por bruxaria: “(1) a exigência de evidências convincentes no que tange ao

${ }^{38}$ DUSSEL. Da Secularização... p. 212.

39 Sobre a temática, inevitável remeter o leitor aos estudos de Michel Foucault (FOUCAULT, Historia de la Locura en la Época Clássica; FOUCAULT, Microfísica do Poder). 'malleficium' e ao pacto; (2) adoção de regras mais rigorosas para o uso da tortura; e (3) a promulgação de decretos restringindo ou eliminando os julgamentos por bruxaria". ${ }^{40}$

Após a insurreição jurisprudencial dos Tribunais franceses, sobretudo em Paris, a edição das Ordonnances reais de 1670 e 1680, apesar de não romper com a lógica inquisitorial do processo penal, pois mantém concentrada nas mãos do julgador a gestão da prova (princípio unificador do sistema), ${ }^{41}$

${ }^{40}$ LEVACK. A Caça... p. 230.

41 No que tange à diferenciação entre os sistemas inquisitório e acusatório, bem como a nota que lhes caracteriza, imprescindível verificar os ensinamentos de Jacinto Coutinho: “(...) a diferenciação destes dois sistemas processuais [inquisitório e acusatório] faz-se através de tais princípios unificadores, determinados pelo critério de gestão da prova. Ora, se o processo tem por finalidade, entre outras, a reconstituição de um fato pretérito, o crime, mormente através da instrução probatória, a gestão da prova, na forma pela qual ela é realizada, identifica o princípio unificador. Com efeito, pode-se dizer que o sistema inquisitório, regido pelo princípio inquisitivo, tem como principal característica a extrema concentração de poder nas mãos do órgão julgador, o qual detém a gestão da prova. Aqui, o acusado é mero objeto de investigação e tido como o detentor da verdade de um crime, da qual deverá dar contas ao inquisidor" (COUTINHO. Introdução aos Princípios Gerais do Direito Processual Penal Brasileiro. p. 29).

Ao avaliar a estrutura do sistema brasileiro, o autor realiza interessante paralelo com a Ordonnance Criminelle de 1870: “(...) pode-se concluir que o sistema processual penal brasileiro é, na essência, inquisitório, porque regido pelo princípio inquisitivo, já que a gestão da prova está, primordialmente, nas mãos do juiz, o que é imprescindivel para a compreensão do Direito Processual Penal vigente no Brasil. No entanto, como é primário, não há mais sistema processual puro, razão pela qual temse, todos, como sistemas mistos. Não obstante, não é preciso grande esforço para entender que não há e nem pode haver - um princípio misto, o que, por evidente, desfigura o dito sistema. Assim, para 
instaura um procedimento de partes restringindo o uso da tortura, operando como minimizador no processo de criminalização da heresia.

A Ordonnance Criminelle de 1670, não obstante ser um "monumento [laico] dell'ingegno inquisitoriale", ${ }^{42}$ contém dois dispositivos que explicam o refluxo persecutório. ${ }^{43} \mathrm{O}$ primeiro dispositivo diz respeito à restrição do uso da tortura. Segundo o artigo $7^{\circ}$, Título XIX, as decisões que permitiam o uso da tortura não poderiam ser executadas a não ser quando fossem confirmadas pelo Tribunal de Paris. E, no sentido de vincular a condenação à reapreciação necessária ao Tribunal incorporando as decisões anteriormente mencionadas -, o artigo $6^{\circ}$, Título XXVI, da Ordonnance, estabelecia que em caso de sentença pronunciada pelos juízes das localidades, condenando o imputado à pena

entendê-lo, faz-se mister observar o fato de que, ser misto significa ser, na essência, inquisitório ou acusatório, recebendo a referida adjetivação por conta dos elementos (todos secundários), que de um sistema são emprestados ao outro. É o caso, por exemplo, do processo comportar a existência de partes, o que para muitos, entre nós, faz o sistema tornar-se acusatório. No entanto, o argumento não é feliz, o que se percebe por uma breve avaliação histórica: quiçá o maior monumento inquisitório fora da Igreja tenha sido as Ordonnance Criminelle (1670), de Luis XIV, em França; mas mantinha um processo que comportava partes" (COUTINHO. Introdução... p. 29).

${ }^{42}$ CORDERO. Guida... p. 47.

${ }^{43}$ Importante notar que sua marca a inquisitorial, por si só, estabelece um modelo persecutório maximizado. O que se está a frisar é que determinados aspectos da Ordonnance Criminelle de 1670 restringem o direcionamento das estruturas policialescas à heresia, não significando, pelo contrário, um processo global de alteração da lógica processual. corporal, galés, banimento perpétuo ou confissão pública, havendo apelo ou não, deveria ser o acusado e seu processo enviados à Corte da metrópole.

A importância da tortura como meio de prova no mecanismo inquisitorial do Medievo foi determinante na proliferação das condenações. Com sua limitação, seja pela via legislativa ou pela prudência de alguns magistrados - "na segunda metade do século XVII, porém, os juízes tornaram-se cada vez mais criteriosos na admissão desta prova, o que dificultou muito a implementação dos julgamentos" ${ }^{44}$-, inevitável o decréscimo criminalizador. Todavia, é a Ordonnance Criminele de 1682, igualmente assinada por Luis XIV, que marcará o esvaziamento do conceito de heresia, apontando para o fim das perseguições na França. O edito real deixa de mencionar crimes de Lesa Majestade Divina e tipifica novas formas de ilicitude. A feitiçaria passa a ser considerada superstição, sendo substituída por duas classes de injusto: envenenamento e sedução; a magia deslocada à crime acessório; o sacrilégio, contudo, em decorrência das condutas de profanação de símbolos e divindades, prossegue penalizado com a morte.

No entanto, se desde o ponto de vista jurídico-penal as velhas tradições são objetadas, o fascínio da caça às bruxas e perseguição dos hereges permanecerá vivo por décadas - “(...) a curiosidade demoníaca dos eruditos não esmoreceu ainda, sem falar na perseverança com a qual certos meios devotos, nostálgicos das cabalas do século precedente, continuam a denunciar os

\footnotetext{
${ }^{44}$ LEVACK. A Caça... p. 231.
} 
feiticeiros. Até meados do século XVIII, a rubrica demonológica continua a ser afreguesada nas prateleiras das livrarias: quer reedições de 'clássicos' como a 'magia natural' de Porta ou as 'histórias' de Rosset; quer novas compilações que tendem claramente a desacreditar os antigos demonólogos". 45

\subsection{O discurso punitivo da modernidade:} o humanismo e o racionalismo

Se do ponto de vista procedimental as dúvidas levantadas pela medicina suscitam a alteração no enfoque jurisprudencial, desde o local da filosofia e da política são os movimentos humanistas e racionalistas que fomentam a crítica aos valores inquisitoriais.

A partir do florescimento do humanismo e do racionalismo, as reformas da cultura medieval, de forma genérica, e das técnicas processuais, em sentido estrito, apresentam como incompatíveis métodos probatórios de "busca da verdade (real)" fundados em intervenções corporais e psicológicas rudimentares. A incisiva luta para erradicação da tortura, como meio probante, e da morte, como pena, é a expressão mais nítida desta política humanista ilustrada.

Prieto Sanchís apresenta os dois pilares do pensamento ilustrado que fomentarão a ruptura com a tradição inquisitorial: "de un lado, el racionalismo jurídico propugnaba abiertamente el monopolio exclusivo del 'ius puniendi', en manos del Estado, supriendo todo residuo señorial; pero de otra parte, el humanitarismo y la filantropia exigían limitar la desbordante y en ocasiones

\footnotetext{
${ }^{45}$ MANDROU. Magistrados e Feiticeiras... p. 396.
}

arbitraria faculdad punitiva del poder. Era preciso, pues, fortalecer el Estado y, al mismo tiempo, limitarlo y dulcificarlo. (...) Mantener y fortalecer el monopolio estatal del uso legítimo de la fuerza, pero limitando su alcance y su rigor en nombre de los derechos individuales y de la dignidad humana, limitar el poder del Estado en un sentido plenamente moderno y liberal". ${ }^{46}$

As teorias humanistas, plenamente apropriadas pelo discurso do liberalismo penal divulgado pela "Escola Clássica", solidificarão a estrutura principiológica do direito e do processo penal, projetando (formalmente) a satisfação da igualdade e a racionalização de um poder punitivo dotado de autonomia, independência e imparcialidade. A instrumentalização desta estrutura ocorrerá fundamentalmente com a densificação do postulado secularizador, cindindo delito (mala prohibita) de pecado (mala in se), sintonizando direito penal do fato e sistema processual penal acusatório em um programa político-criminal minimalista.

\begin{abstract}
"Os fundamentos do direito penal moderno são lançados em bloco pela Ilustração, tendo em vista a coerência de suas proposições: a lei penal - geral, anterior, taxativa e abstrata (legalidade) - advém de contrato social (jusnaturalismo antropológico), livre e conscientemente aderido por pessoa capaz (culpabilidadeflivre arbítrio), que se submete à penalidade (retributiva) em decorrência da violação do pacto por atividade externamente perceptível e danosa (direito penal do fato), reconstituída e comprovada em processo contraditório e público, orientado pela presunção de inocência, com atividade imparcial de magistrado que valora livremente a prova (sistema processual acusatório).
\end{abstract}

${ }^{46}$ SANCHÍS. La Filosofia Penal de la Ilustración: aportación a su estudio. p. 290. 
Assim, percebe-se claramente um programa de intervenção penal limitada cuja centralidade é a tutela dos direitos individuais contra os poderes irracionais, públicos (Estado) elou privados. Sem embargo, tal concepção possibilita um entendimento, ainda que não explícito, pessimista do poder estatal, pois geneticamente propenso à violação dos direitos fundamentais da pessoa humana". ${ }^{47}$

Thomasius, um dos pensadores mais significativos da ruptura com o Medievo penal, defende abertamente a secularização do direito com a dessacralização do delito, a reestruturação processual, sobretudo probatória, e o fim das medidas sancionatórias de caráter redentor. Tarello, em comentários à obra do filósofo alemão, sustenta que " $l a$ doctrina penal de Thomasius representa el puente entre la doctrina penal del absolutismo del setecientos, expressados en el sistema hobbesiano y pufendorfiano, y la doctrina penal del iluminismo del XVIII", ${ }^{48}$

$\mathrm{Na}$ Itália, os postulados liberais da Accademia dei Pugni, capitaneada pelos irmãos Pietro e Alessandro Verri e por Beccaria, adquirirão contornos de universalidade, sobretudo com a excelente recepção dos escritos na França, por intermédio de Voltaire. ${ }^{49}$ Não por outro motivo a obra de

${ }^{47}$ CARVAlho. Pena e Garantias. p. 43.

${ }^{48}$ Apud SANCHÍS. La Filosofia Penal... p. 297.

49 Voltaire, entusiasmado com a consistência dos trabalhos do grupo milanês, recebe em Paris Beccaria e Alessandro Verri para um ciclo de conferências. Após o caloroso acolhimento, Voltaire coordena a tradução e redige a apresentação Comentário sobre o Livro Dos Delitos e Das Penas por um Advogado de Província (1766). No início já depões sobre a importância da obra: "eu estava imbuído da leitura do livrinho Dos Delitos e Das Penas, que é em moral o que são na medicina os poucos remédios com os quais nossos males podem ser aliviados" (VOLTAIRE. Comentário... p. 119).
Beccaria é aclamada na academia como o ponto de partida do direito penal, da criminologia e da política criminal da modernidade. No que tange ao processo penal, os arautos da "Escola Clássica"50

${ }^{50}$ A unidade e a própria existência da conhecida "Escola Clássica" merece alguns questionamentos. Lembra Zaffaroni que as várias vertentes do iluminismo penal “(...) jamás pueden ser colocadas bajo el rótulo de una 'escuela', porque la 'escuela clásica' nunca existió, sino que la inventó Enrico Ferri, como denominación común para todo lo que fue anterior al positivismo. En varias ocasiones hemos demonstrado que no puede ser una 'escuela' el conjunto de opiniones de los pensadores del tema político-criminal durante más de un siglo, vertidas desde las ideologías más dispares (kantismo, hegelianismo, idealismo romántico, utilitarismo, vueltas parciales al aristotelismo, pensamiento iluminista, etc.). Además, la circunstancia de que estos autores, justamente, hayan sido quienes al plantear la cuestión político-criminal dieran origen a la presentación actual de la criminología, nos exime de cualquier comentario acerca de su tradicional asignación al terreno del derecho penal. Más aún: consideramos que su ubicación en el ámbito exclusivo del derecho penal con un rótulo unitario - y su consiguiente exclusión del ámbito criminológico - es un modo de minimizar su importancia y de prevenirse contra el efecto deslegitimador que puede tener el discurso contractualista (ZAFFARONI. Criminología: aproximación desde un margen. p. 128).

Não é lícito, por suposto, questionar a importância da elaboração doutrinária do direito e do processo penal, da política criminal e da criminologia moderna nas obras de Beccaria e de Pietro Verri, todavia, parece equivocado reduzir período tão fértil de construção do discurso sobre o delito, o juízo e a pena ao movimento milanês nominado o rótulo de 'Escola Clássica'. Tal possibilidade pressuporia unidade metodológica, o que não parece ser possível sustentar. No entanto, "se inexiste no interir do 'classicismo' consenso sobre alguns temas basilares da questão penal, percebe-se nítida aproximação teórica quanto à fundamentação filosófico-política do Estado. Tal agregador, até a antecipação do tecnicismo por Francesco Carrara, será a teoria do contrato social. Desta forma, compartilha-se da perspectiva de Zaffaroni quando identifica 'movimentos penais ilustrados' sob a égide 
direcionaram suas críticas fundamentalmente ao uso irrestrito da tortura como mecanismo de produção probatória. ${ }^{51}$

Em solo francês, a teoria penal desloca o eixo do humanismo na perspectiva secularizadora de luta contra a intolerância, reivindicando a tutela dos direitos civis contra o arbítrio punitivo. Jean Paul Marat (Plano de Legislação Criminal, 1779)

do contratualismo. Da transposição das mais diferenciadas idéias contratuais, do plano filosóficopolítico à esfera do jurídico, pode-se propor uma relativa categorização dos movimentos da época" (CARVAlHO. Pena... p. 41/2). Desta forma, talvez a conceituação mais próxima do que representaram os 'movimento penais ilustrados' seja a de contratualismo penal, e, mesmo assim, lembrando as inúmeras vertentes contratuais (Hobbes, Locke, Rousseau, Marat, Feuerbach etc.).

51 Verri, no manifesto Observações sobre a Tortura, argumentava: “(...) se a tortura é útil e justa, talvez eu consiga demonstrar que esta é uma opinião tão infundada quanto foi a feitiçaria" (VERRI. Considerações sobre a tortura. p. 07). Ao relatar o caso dos ungüentos pestíferos de Milão (1630), expõe a tarefa político-humanitária do movimento: "a cena é extremamente cruel, e meu punho transcreve a duras penas; mas se o calafrio que sinto servir para poupar nem que seja apenas uma vítima, se se deixar de infligir uma única tortura graças ao horror do que passo a expor, será bem empregado o doloroso sentimento que me toma, $e$ essa esperança é minha recompensa" (VERRI. Considerações... p. 53/4).

Com o mesmo entusiasmo e horror Becaria exorta o uso da tortura em nome da presunção de inocência: "é uma barbárie consagrada pelo uso na maioria dos governos aplicar a tortura a um acusado enquanto se faz o processo (...). Um homem não pode ser considerado culpado antes da sentença do juiz" (BECCARIA. Dos Delitos e das Penas. p. 63). Prossegue com a mesma ênfase: "Resulta ainda do uso das torturas uma conseqüência bastante notável: é que o inocente se acha numa posição pior que a do culpado. Com efeito, o inocente submetido à tortura tem tudo contra si: ou será condenado, se confessar o crime que não cometeu, ou será absolvido, mas depois de sofrer tormentos que não mereceu" (BECCARIA. Dos Delitos... p. 69). e Brissot de Warville (Teoria das Leis

Criminais, 1777) serão os autores que melhor instrumentalizarão os princípios do iluminismo penal, mormente imprimirem ao liberalismo versão socialista utópica, formulando importantes projetos de reforma das instituições jurídico-penais. ${ }^{52}$

\section{CONSIDERAÇÕES FINAIS:}

A DESCONSTRUÇÃO DO SISTEMA INQUISITÓRIO CONFESSIONAL E O NASCIMENTO (E MANUTENÇÃO) DO MODELO INQUISITORIAL LAICO

\begin{abstract}
“(...) pouco a pouco as versões do texto se enterram cada vez mais profundamente, mas nesse trabalho de esquecimento, as reclassificações intervêm para modernizar periodicamente o invólucro do sistema" (Pierre Legendre)
\end{abstract}

O processo de laicização do direito penal e processual penal, principalmente no direito francês, é consequiência de algumas causas trabalhadas neste artigo, dentre inúmeras que poderiam ser expostas, visto a natureza transdisciplinar da temática "Medievo". $\mathrm{O}$ texto restringiu-se, porém, à mudança na concepção de heresia desde o discurso médico e sua recepção pela jurisprudência, aliada ao processo de universalização das bases humanistas e racionalistas do liberalismo ilustrado. Nota-se, contudo, que o humanismo e o racionalismo estão inseridos no câmbio de concepção do próprio Direito Natural, ou seja, da sobreposição do jusnaturalismo antropológico ao teocêntrico. Assim, o processo que culmina com a erradicação do delito de heresia,

52 Sobre a contribuição de Marat e sua antecipação da Criminologia Crítica, conferir CARVALHO. Pena... pp. 47-52. 
simbolizando a ruptura secular entre delito e pecado, representa mudança nuclear no que tange à legitimidade dos sistemas jurídicos. Se os processos inquisitoriais eram justificados a partir da teoria jusnaturalista de ênfase teológica, a Ilustração igualmente utilizará fundamento de direito natural, porém de sustentação humanitária. Despreza-se o direito natural revelado em prol de um direito natural conquistado pela revolução racionalista.

Contudo, resta indagar, em decorrência das hipóteses pontuadas anteriormente, se a teia prático-teórica de princípios que altera o eixo do direito natural centralizando-o no homem realmente representou uma ruptura com a lógica inquisitorial.

A superação da crença teológica e a tentativa de sobreposição da razão com a finalidade de impor uma racionalidade na atuação dos atores processuais indicam inegável tendência de secularização na esfera do direito processual penal. Na esfera do direito penal material, a delimitação do delito na norma (princípio da legalidade) estabelece nítida ruptura com a antiga conjugação entre crime e pecado. Desde esta perspectiva, é preciso reconhecer que o movimento da Ilustração foi fundamental para o estabelecimento de uma visão completamente nova das estruturas jurídico-penais, opondose àquela racionalidade que sustentava o poder repressivo de um Príncipe legitimado pelo Clero. Somente a partir do liberalismo penal foi possível dinamizar uma teoria dos Direitos Humanos e destronar o discurso penal genocida sustentado pela Inquisição. Como lembra Mandrou, "o estabelecimento desta nova jurisprudência faz parte do esforço realizado no século XVII para superar o obstáculo metafísico interposto à constituição de uma ciência e de um pensamento fundamentados na razão. Constitui uma ilustração - a mais bela talvez - de uma crise de consciência, que é também, por imagem, uma crise de crescimento". ${ }^{53}$

No entanto, é imprescindível perceber, para que a avaliação histórica não represente mero exercício lúdico de academia, que as reformas oitocentistas no discurso penal e processual penal, ponto máximo do processo que se inicia no século XVI, apesar de estabelecerem como variável fundamental a secularização, com a radical separação entre direito (delito) e moral (pecado), não lograram exorcizar a lógica inquisitorial da cultura penal do Ocidente. Lembra Legendre que se os movimentos de secularização na Europa “(...) desfizeram progressivamente ou brutalmente, segundo os vínculos da instituição com a Igreja e seu Direito pontifício, não destruíram o edifício tradicional do qual o direito romano era, também ele propagador. (...) No caso do nacionalismo francês, a fundação do Estado napoleônico, onde a referência romana devia ser tão eficaz (temas do cônsul, depois do imperador, remissão alegórica a Justiniano codificador das leis romanas, etc.), ilustra à maravilha esse jogo de máscaras". 54

${ }^{53}$ MANDROU. Magistrados e Feiticeiras... p. 455.

${ }^{54}$ LEGENDRE. $O$ Amor... p. 91. Prossegue, ainda, o autor: "sabemos tão pouco a esse respeito, que deveríamos ter o cuidado de não julgar demasiado sumariamente o processo de laicização do Poder $e$ seu modo de reprodução do conflito, do qual a sexologia tradicional dava conta. Eu adianto apenas isso: não se trata de saber se o clero perdeu ou não a sua prestança, mas de identificar a categoria supletiva e o estilo mais ou menos novo para tratar o Pai imaginário" (LEGENDRE. O Amor... p. 179). 
Com o ápice do movimento ilustrado na Revolução de 1789, o Constituinte francês (1791) e posteriormente o Legislativo (v.g. Lei 16/1791), importando as técnicas processuais inglesas que, desde a Magna Carta de 1215 fixavam o sistema acusatório, ${ }^{55}$ reorganizam a estrutura do processo penal. Todavia, como leciona Jacinto Coutinho, “(...) antes do 'terror' havia espaço para uma tentativa de reconhecimento da democracia processual, inimaginável com Napoleão, um ditador como qualquer outro que, entre outras coisas, influenciou diretamente um retorno à estrutura do ancien regime (o espírito inquisitório seduz gente de tal porte, em qualquer lugar e época)". ${ }^{56}$

Com o Código de Napoleão, fonte inspiradora de grande parte da legislação processual penal de tradição latina, nasce o "processo misto". Cordero sintetiza o efeito desta elaboração legislativa: "e assim, pela Lei de 17 de novembro de 1808, nasce o chamado processo misto, monstro de duas cabeças: nos labirintos escuros da instruction [instrução preliminar] reina Luís $X I V$; segue uma cena disputada coram populo. Para alguns um capolavoro [obra prima] (...). Jean Constantin, Charles Domoulin, Pierre Ayrault, julgam-na menos bem: existe um abismo, nota o último, entre 'instrução secreta' e pública; 'é fácil a portas

55 “O processo penal inglês, assim, dentro do common law, nasce como um autêntico processo de partes, diverso daquele antes existente. Na essência, o contraditório é pleno; e o juiz estatal está em posição passiva, sempre longe da colheita da prova" (COUTINHO. O Papel... p. 40).

56 COUTINHO. $O$ papel... p. 41. fechadas ajustar ou diminuir, produzir brigas ou impressões'; a audiência pública garante um trabalho limpo; 'haverá sempre alguma coisa a ser dita novamente' sobre os juízos não produzidos em público, do começo ao fim; 'esta face composta de mais olhos, mais orelhas, mais cabeças, que aquelas de todos os monstros e gigantes dos poetas tem mais força... para penetrar até as consciências e ali ler de que lado está o bom direito, que a nossa instrução tão secreta". 57

Parece, pois, que a conclusão possível após esta leitura da história da organização da persecução penal é de que o processo de desconstrução do sistema processual, operado na Ilustração a partir da idéia de secularização, obteve como êxito "parcial laicização". Com as Ordonnances (1670 e 1682) de Luís XIV obtém-se um modelo inquisitório não confessional de instrução criminal o qual, com a recapacitação auferida por Napoleão, torna-se “o" sistema processual penal - "o mito escolástico foi retrabalhado, reformado, retranscrito, mas não demolido". 58

57 CORDERO. Guida... p. 73/4 [As traduções dos originais italianos das obras de Cordero (Guida alla Procedura Penale e Procedura Penale) e de Humberto Eco (Il nome della rosa), apresentadas ao longo do texto, foram realizadas livremente. A tradução do presente trecho da Guida (Processo Misto, do item Apogeo, declinio e metastasi dello stile inquisitório, do capítulo Storia dei Sistemi), é de Jacinto Coutinho, apresentada no painel $O$ Projeto de Lei 4.209 - Investigação Criminal da IV Jornadas Brasileiras de Direito Processual Penal, realizadas pelo Instituto Brasileiro de Direito Processual, Guarujá (SP), 07.11.04. Em face do rigor do trabalho, optou-se, neste momento, por poupar o leitor da tradução/traição livre].

58 LEGENDRE. O Amor... p. 181. 
A burla de etiquetas do Código Napoleônico (Processo Misto) apenas mantém viva estrutura cuja principal característica primordial é a concentração dos poderes instrutórios na figura do juiz (ator): "Napoleão recriou um Justiniano imaginário, personagem simbólico outrora venerado pelos medievais, edificadores do Direito Canônico pontifício". 59

A institucionalização do sistema acusatório pela Revolução Francesa e a breve experiência (1789-1810) sepultada por um poder autoritário apenas revelam a triste conclusão de que, nos países de tradição jurídica latina, das garantias processuais gozadas desde 1215 na tradição do common law restou apenas o gosto de um triunfo não gozado.

Por fim, como referi em outro momento, “(...) a biografia das práticas penais, apesar de sua sinuosidade, tem demonstrado que a regra do poder penal é o inquisitorialismo, ou seja, que o discurso garantista de gênese ilustrada configurou uma variável insensata na estrutura das formas de poder, uma cisão acidental na história das violências da qual somos herdeiros inocentes, românticos poetas de um passado imaginário". 60

59 LEGENDRE. $O$ Amor... p. 175. Legendre especifica sua constatação: “(...) de alto a baixo, $e$ até ao mais baixo, a Administração oferece o espetáculo feudal de extratos encaixados uns nos outros, solidificados à maneira feudal, como já havia tão bem entrevisto Saint-Simon quando enunciou que Napoleão e os seus tinham refeudalizado a França" (LEGENDRE. O Amor... p. 199).

${ }^{60}$ CARVALHO. Tântalo no Divã. p. 117.

\section{BIBLIOGRAFIA}

ASUA BATARRITA, Adela (Coord.). El Pensamiento Penal de Beccaria: su actualidad. Bilbao: Universidad de Deusto, 1990.

BAUBÉROT, Jean. Laicidade. In: CANTOSPERBER, Monique (Org.). Dicionário de Ética e Filosofia Moral (II). São Leopoldo: EdUNISINOS, 2003.

BECCARIA, Cesare de. Dos Delitos e das Penas. 6. ed. São Paulo: Atena, 1959.

BOFF, Leonardo. Inquisição: Um espírito que continua a existir. In: EYMERICH, Nicolau. Manual dos Inquisidores. Rio de Janeiro: Rosa dos Tempos; Brasília: EdUnB, 1993.

BORNHEIM, Gerd. A Descoberta do Homem e do Mundo. In: NOVAES, Adauto (Org.). A Descoberta do Homem e do Mundo. São Paulo: Companhia das Letras, 1998.

CARVALHO, Salo. Pena e Garantias. 2. ed. Rio de Janeiro: Lumen Juris, 2003.

CARVALHO, Salo. Tântalo no Divã. Revista Brasileira de Ciências Criminais (50). São Paulo: RT, 2004.

CORDERO, Franco. Guida alla Procedura Penale. Torino: Utet, 1986.

CORDERO, Franco. Procedura Penale. 5. ed. Milano: Giuffrè, 2000.

COUTINHO, Jacinto. Introdução aos Princípios Gerais do Direito Processual Penal Brasileiro. Revista de Estudos Criminais (01). Sapucaia do Sul: ITEC/Notadez, 2000.

COUTINHO, Jacinto. O Papel do Novo Juiz no Processo Penal. Direito Alternativo: anais do evento comemorativo do Sesquicentenário do Instituto dos Advogados Brasileiros. Rio de Janeiro: IAB, 1994.

DUSSEL, Enrique D. Da Secularização ao Secularismo da Ciência Européia, desde o Renascimento até o Iluminismo. In Caminhos para Libertação Latino-Americana (II). São Paulo: Paulinas, 1984.

EYMERICH, Nicolau. Manual dos Inquisidores. RJ: Rosa dos Tempos; Brasília: EdUnB, 1993.

FOUCAULT, Michel. Vigiar e Punir. 8. ed. Petrópolis: Vozes, 1991. 
FOUCAULT, Michel. Historia de la Locura en la Época Clássica. 2. ed. México (DF): Fondo de Cultura, 1992.

FOUCAULT, Michel. Microfísica do Poder. 6. ed. Rio de Janeiro: Graal, 1986.

FREUD, Sigmund. Una dificultad del Psicoanalisis. In: Obras Completas (III). Madrid: Biblioteca Nueva, 1996.

GONZAGA, João Bernardino. A Inquisição em seu Mundo. São Paulo: Saraiva, 1993.

JARDIM, Afrânio Silva. Ação Penal Pública: princípio da obrigatoriedade. 2. ed. Rio de Janeiro: Forense, 1994.

KRAMER, Heinrich \& SPRENGER, James.

O Martelo das Feiticeiras. 8. ed. Rio de Janeiro: Rosa dos Tempos, 1991.

LEGENDRE, Pierre. O Amor do Censor: ensaio sobre a ordem dogmática. Rio de Janeiro:

Colégio Freudiano; Forense Universitária, 1983.

LEVACK, Brian. A Caça às Bruxas. 2. ed. Rio de Janeiro: Campus, 1989.

MANDROU, Robert. Magistrados e Feitiçeiras na França do Século XVII. São Paulo:

Perspectiva, 1979.
NOVINSKY, Anita. A Inquisição. 2. ed. São Paulo: Brasiliense, 1983.

NOVINSKY, Anita. \& CARNEIRO, Ma. Luiza Tucci (Orgs). Inquisição: Ensaios sobre mentalidade, heresias e arte. Rio de Janeiro: Expressão e Cultura; São Paulo. EDUSP, 1992. SANCHÍS, Luis Prieto. La Filosofia Penal de la Ilustración. Aportación a su estudio. Anuario de Derechos Humanos (03). Madrid: Universidad Complutense, 1985.

VERRI, Pietro. Observações sobre a Tortura. São Paulo: Martins Fontes, 1992.

VOLTAIRE, François Ma. Arouet. Comentário sobre o Livro Dos Delitos e Das Penas por um Advogado de Província. In Comentários Políticos. São Paulo: Martins Fontes, 2001.

ZAFFARONI, Eugenio Raul. Criminologia: aproximación desde un margen. Bogotá: Temis, 1988.

ZAFFARONI, Eugenio Raul; BATISTA, Nilo; SLOKAR, Alessandro e ALAGIA, Alessandro. Direito Penal Brasileiro. Rio de Janeiro: Revan, 2003. 